\title{
ESTIMATION OF DYNAMIC LOADS ON A REFERENCE TRAIN WITH A PASSIVE SAFETY SYSTEM IN ITS COLLISIONS WITH AN IDENTICAL TRAIN AND A FREIGHT CAR
}

\author{
Institute of Technical Mechanics \\ of the National Academy of Sciences of Ukraine and the State Space Agency of Ukraine \\ 15 Leshko-Popel St., Dnipro 49005, Ukraine; e-mail: dep7@ukr.net
}

New high-speed passenger cars for $1520 \mathrm{~mm}$ gage railways must be designed taking into account passive safety systems (PSSs) for collision protection. A PSS includes energy absorbing devices (EADs), which protect the passengers, the train crew, and the car structures from destructive impact loads. At the Institute of Technical Mechanics of the National Academy of Sciences of Ukraine and the State Space Agency of Ukraine, EADs of different absorbing capacities have been designed. The aim of this paper is to estimate dynamic loads on the PSSequipped vehicles of a reference train in collisions whose scenarios are specified in the EN 15227 standard. In this paper, collisions of a reference train at $36 \mathrm{~km} / \mathrm{h}$ with an identical train and with $80 \mathrm{t}$ freight car are considered. The reference train consists of a locomotive and four cars whose end parts are equipped with EADs. A discretemass model of a head-on train collision is presented. What is new in the model is the force characteristic of an inter-car connection, which takes into account the operation of the locomotive and car push-back automatic couplers and EADs and the elastoplastic deformation of the vehicle structures. Two trains are considered: a $90 \mathrm{t}$ locomotive with $50 \mathrm{t}$ cars and a $123 \mathrm{t}$ locomotive with $64 \mathrm{t}$ cars. It is shown that the requirements of the European EN 15227 standard and the passive protection concept developed for a $1520 \mathrm{~mm}$ gauge high-speed passenger train are met if the locomotive, $50 \mathrm{t}$ cars, and $64 \mathrm{t}$ cars are equipped with EADs of energy absorbing capacity $0.95 \mathrm{MJ}, 0.25 \mathrm{MJ}$, and 0.3 MJ, respectively. Locomotive and car EAPs with these values of the energy absorbing capacity have been designed.

keywords locomotive-hauled high-speed passenger train, collision, passive safety system, energy absorbing device.

1. Principal Aspects of the Development Strategy of JSC "Ukrzaliznytsia" for 2017 - 2021 (in Ukrainian). URL:http://www.uz.gov.ua/files/file/Strategy_Presentation_fin1.pdf (Last accessed: Sept.15, 2017).

2. Program (Predictive) of JSC "Ukrzaliznytsia" Rolling Stock Updating up to 2021 and its Implementation in 2017 (in Ukrainian). URL: http://eurotrain.railway-publish.com/assets/files/pdf/1.pdf (Last accessed: Sept. 15, 2017).

3. Railway Transport of Ukraine 2016-2017 (in Ukrainian). URL: http://eurotrain.railwaypublish.com/assets/files/pdf/5.pdf (Last accessed: Sept. 15, .2017).

4. EN 15227. Railway applications - Crashworthiness requirements for railway vehicle bodies. Brussels, 2008. $37 \mathrm{pp}$.

5. Carl F.B., Schneider S., Wolter W. Development of the crashworthy locomotive platform TRAXX: Operational needs, technical concept and validation procedure. Passive Safety of Rail Vehicles and Safe Interiors. Proceedings of 5th International Symposium (17 - 18 March, 2005, Berlin). Berlin, 2005. Pp. 42-62.

6. The EST crash buffer. URL: http://www.crashbuffer.com/index.htm (Last accessed: Sept. 15, 2017).

7. Foedtke J., Schneider S., Pfrommer R., Zurheide H. Entwicklung der Kastenstruktur für die Lokomotive Voith Maxima 40C. Design of the carbody structure for the Voith Maxima 40CC locomotive. ZEVrail Glasers Annalen. 2008. No. 132. p. 292-303.

8. Prima II - locomotives of new generation (in Russian). Zheleznye Dorogi Mira. 2010. No. 12. Pp. 17-25.

9. Siemens. Locomotives. Integrated Solutions for Efficient Passenger Traffic and Goods Transportation (in Russian). URL: http://eurotrain.railway-publish.com/assets/files/pdf/12.pdf (Last accessed: Sept 15, 2017).

10. Coupling and Protection. Coupling Devices and Systems for the Front Part of a Train (in Russian). URL: http://resource.voith.com/vt/publications/downloads/1994_r_g1712_rus_2013-03.pdf (Last accessed: Sept. $15,2017)$.

11. Jade E. Development process of a side bumper crash device. Passive Safety of Rail Vehicles. Innovation in passive safety and interior design. Proceedings of the 7th International Symposium (20-21 November 2008, Berlin). Berlin, 2008. Pp. 71-80.

12. Wasilewski L. Evolution of crash absorbing systems according to EN 15227 and according to real operation conditions. Passive Safety 2013 - Passive Safety of Rail Vehicles and Safe Interiors. Proceedings of the 9th International Symposium (21-22 February 2013, Berlin). Berlin, 2013. Pp. 211-218.

13. Axtone is the supplier of the largest crash buffers in Europe. URL: http://www.crashtechnology.eu/news/task,item/id,10/ (Last accessed: Sept. 15, 2017).

14. Innova Systems \& Technologies. Railway technologies \& crash buffers. URL: http://www.innovasystech.com/ (Last accessed: Sept. 15, 2017).

15. Sobolevska M. B., Sirota S. A. Basics of a passive protection concept for a high-speed passenger train in 
emergency collisions (in Russian). Tekhnicheskaya Mekhanika. 2015. No. 1. Pp. 84-96.

16. Naumenko N. Yu., Sobolevska M. B., Gorobets D. V., Bogomaz E. G. Development of crashworthy components for passive protection of $1520 \mathrm{~mm}$ gage high-speed passenger locomotives of new generation in emergency collisions (in Russian). 2017. No. 1. Pp. 72-82.

17. Naumenko N. Yu., Sobilevska M. B., Sirota S. A., Gorobets D. V. Development of crashworthy components for passive protection of $1520 \mathrm{~mm}$ gage passenger cars of new generation (in Russian). Technical Mechanics. 2017. No, 2. Pp. 73-83.

18. Naumenko N. Yu., Khizha I. Yu. Simulation of an emergency collision between a passenger train equipped with a passive safety system and an obstacle (in Russian). Tekhnicheskaya Mekhanika. 2014. No, 4. Pp. 6574.

19. Llana P., Stringfellow P. Preliminary finite element analysis of locomotive crashworthy components. ASME 2011 Rail Transportation Division Fall Technical Conference RTDF011, September 21 - 22, 2011, Minneapolis, Minnesota, USA: proceedings. Minneapolis, 2011. Pp. 1-11.

20. Llana P., Stringfellow $R$. Preliminary development of locomotive crashworthy components. ASME/ASCE/IEEE Joint Rail Conference JRC2011, March 16 - 18, 2011, Pueblo, Colorado, USA: proceedings. Pueblo, 2011. Pp. 11-20.

21. Naumenko N. Yu., Khizha I. Yu. Estimation of the effect of the operation of the passive safety system of a passenger locomotive on dynamic loads thereon in an emergency collision with an obstacle (in Russian). Nauka ta Progres Transportu, Visnyk Dnipropetrovskogo Natsionalnogo Universytetu Zaliznychnogo Transportu im. Akad. V. Lazariana. 2013. No, 1 (43). Pp. 154-161.

22. Naumenko N. Yu., Khizha I. Yu. Simulation of the interaction between the vehicles of a passenger train equipped with a passive safety system in an emergency collision with an obstacle (in Russian). Nauka ta Progres Transportu, Visnyk Dnipropetrovskogo Natsionalnogo Universytetu Zaliznychnogo Transportu im. Akad. V. Lazariana. 2015. No. 4 (58). Pp. 163-174. 